Article

\title{
Implementation of Extended Statistical Entropy Analysis to the Effluent Quality Index of the Benchmarking Simulation Model No. 2
}

Alicja P. Sobańtka ${ }^{1, *}$, Marie-Noëlle Pons ${ }^{2}$, Matthias Zessner ${ }^{1,3}$ and Helmut Rechberger ${ }^{1,3}$

1 Centre for Water Resource Systems, Vienna University of Technology, Karlsplatz 13/222, Vienna A-1040, Austria; E-Mails: m.zessner@iwag.tuwien.ac.at (M.Z.); helmut.rechberger@tuwien.ac.at (H.R.)

2 Laboratoire Réactions et Génie des Procédés (UMR 7274 CNRS), Université de Lorraine, 1, rue Grandville, BP 20451, Nancy F-54001, France; E-Mail: marie-noelle.pons@univ-lorraine.fr

3 Institute for Water Quality, Resource and Waste Management, Vienna University of Technology, Karlsplatz 13/226, Vienna A-1040, Austria

* Author to whom correspondence should be addressed; E-Mail: alicja.p.sobantka@gmail.com; Tel.: +43-1-58801-406656; Fax: +43-1-58801-22697.

Received: 17 October 2013; in revised form: 23 December 2013 / Accepted: 25 December 2013 / Published: 2 January 2014

\begin{abstract}
Extended statistical entropy analysis (eSEA) is used to assess the nitrogen (N) removal performance of the wastewater treatment (WWT) simulation software, the Benchmarking Simulation Model No. 2 (BSM No. 2 ). Six simulations with three different types of wastewater are carried out, which vary in the dissolved oxygen concentration $\left(\mathrm{O}_{2}\right.$,diss. $)$ during the aerobic treatment. $\mathrm{N}_{2} \mathrm{O}$ emissions generated during denitrification are included in the model. The N-removal performance is expressed as reduction in statistical entropy, $\Delta \mathrm{H}$, compared to the hypothetical reference situation of direct discharge of the wastewater into the river. The parameters chemical and biological oxygen demand (COD, BOD) and suspended solids (SS) are analogously expressed in terms of reduction of COD, $\mathrm{BOD}$, and SS, compared to a direct discharge of the wastewater to the river $\left(\Delta \mathrm{EQ} \mathrm{P}_{\text {rest }}\right)$. The cleaning performance is expressed as $\Delta \mathrm{EQ}_{\text {new }}$, the weighted average of $\Delta \mathrm{H}$ and $\Delta \mathrm{EQ}_{\text {rest }}$. The results show that $\triangle \mathrm{EQ}_{\text {new }}$ is a more comprehensive indicator of the cleaning performance because, in contrast to the traditional effluent quality index (EQ), it considers the characteristics of the wastewater, includes all $\mathrm{N}$-compounds and their distribution in the
\end{abstract}


effluent, the off-gas, and the sludge. Furthermore, it is demonstrated that realistically expectable $\mathrm{N}_{2} \mathrm{O}$ emissions have only a moderate impact on $\Delta \mathrm{EQ}_{\text {new }}$.

Keywords: Benchmarking Simulation Model; extended statistical entropy analysis; nitrogen; nitrous oxide; wastewater treatment

\section{Introduction}

The Benchmarking Simulation Model No 2 (BSM No. 2) models an activated sludge large-scale wastewater treatment plant (WWTP) at the level of the whole plant aiming at a more stable and improved effluent quality. The BSM No. 2 considers both pretreatment of the wastewater and sludge treatment, thus, including seasonal effects on the WWTP in terms of temperature variations and changing influent flow rate patterns [1]. The effluent quality is measured by the Effluent Quality Index (EQ), which considers the loads of suspended solids (SS), chemical and biological oxygen demand (COD, BOD), Kjeldahl-N [TKN: organically bound nitrogen $\left(\mathrm{N}_{\text {org }}\right)$ plus ammonium $\left(\mathrm{NH}_{4}{ }^{+}\right)$], and nitrate $\left(\mathrm{NO}_{3}\right)$. Every parameter is attached with an individual weighting factor to reflect the particular ecological harming potential. In the BSM No. 2, $\mathrm{N}_{\text {org }}$ is differentiated as soluble biodegradable $\mathrm{N}_{\text {org }}$ (SBN) and particulate biodegradable $\mathrm{N}_{\text {org }}(\mathrm{PBN})$. However, the EQ does not differentiate between $\mathrm{NH}_{4}{ }^{+}$, SBN, and PBN. Furthermore, gaseous losses such as $\mathrm{N}_{2} \mathrm{O}$ are disregarded. Yet, $\mathrm{N}_{2} \mathrm{O}$ emissions caused by WWT are important due to the great greenhouse gas (GHG) potential of $\mathrm{N}_{2} \mathrm{O}$, which is 296 times larger than the potential of $\mathrm{CO}_{2}$ and because wastewater is worldwide the sixth largest contributor to $\mathrm{N}_{2} \mathrm{O}$ emissions [2,3]. It was found that the $\mathrm{O}_{2}$ concentration in the aeration tanks is one of the main operational parameters influencing the production of $\mathrm{N}_{2} \mathrm{O}$ [4,5]. At $\mathrm{O}_{2}$ concentrations of $1 \mathrm{mgO}_{2} / \mathrm{L} \mathrm{N}_{2} \mathrm{O}$ emissions increase due to incomplete nitrification compared to the default open-loop control strategy. $\mathrm{O}_{2}$ concentrations below $1 \mathrm{mg} / \mathrm{L}$ can cause $\mathrm{N}_{2} \mathrm{O}$ emissions that correspond to $10 \%$ of the initial N-load [6]. Other studies confirm that low $\mathrm{O}_{2}$ concentrations lead to increased $\mathrm{N}_{2} \mathrm{O}$ emissions [7-11]. On the other hand, $\mathrm{O}_{2}$ concentrations of $3 \mathrm{mgO}_{2} / \mathrm{L}$ also lead to increased $\mathrm{N}_{2} \mathrm{O}$ emissions due to incomplete denitrification, caused by recirculation of the $\mathrm{O}_{2}$ from the aerobic to the anoxic reactor [12]. The estimation of GHG emissions related to WWT processes has been solved through different modeling approaches [13-15]. Snip and colleagues model $\mathrm{N}_{2} \mathrm{O}$ emissions within the BSM No. 2 disregarding the potential emissions from the aerobic process. They, in turn, find that a change in the $\mathrm{NH}_{4}^{+}$concentration has the highest effect on the $\mathrm{N}_{2} \mathrm{O}$ production, whereas the $\mathrm{O}_{2}$ concentration has almost no influence [13]. The degree of accumulated $\mathrm{NH}_{4}{ }^{+}$at the end of the anoxic phase effectively enhances the $\mathrm{N}_{2} \mathrm{O}$ production [7,16,17]. Based on the BSM No. 2, it is also shown that in addition to the $\mathrm{O}_{2}$ concentration, the control of the internal recycle flow and the SS significantly influence the $\mathrm{N}_{2} \mathrm{O}$ emissions [12]. Furthermore, other parameters such as temperature, $\mathrm{pH}$, and even the copper concentration in the wastewater are found to have a considerable effect on the $\mathrm{N}_{2} \mathrm{O}$ production [8,15,18-20]. Recent findings show a seasonal dynamic of $\mathrm{N}_{2} \mathrm{O}$ emissions, which is not yet fully understood [21]. A comprehensive review of literature, published in 2011, on parameters affecting $\mathrm{N}_{2} \mathrm{O}$ emissions from WWT facilities is presented in [22]. However, $\mathrm{N}_{2} \mathrm{O}$ emissions have the 
potential of being important but are not yet considered in the assessment of the N-removal performance and the overall cleaning performance.

Apart from its importance for the $\mathrm{N}_{2} \mathrm{O}$ production the dissolved $\mathrm{O}_{2}$ has been determined as one of the most important process variables influencing the entire nitrification and denitrification process, thus affecting the N-removal performance of the WWT [23]. Its effect is, however, determined by other process parameters, such as temperature, $\mathrm{pH}$, sludge age, and particularly for the denitrification process the concentration of dissolved organic carbon (DOC). Based on studies performed using the BSM No. 2, it was derived that the process control that regulates the $\mathrm{O}_{2}$ concentration in two aeration tanks each to $2 \mathrm{gO}_{2} / \mathrm{m}^{3}$ and $1 \mathrm{gO}_{2} / \mathrm{m}^{3}$ yields a lower total $\mathrm{N}$ and a lower $\mathrm{NO}_{3}{ }^{-}$load in the effluent, compared to an operating condition where the dissolved $\mathrm{O}_{2}$ concentration is set to $2 \mathrm{gO}_{2} / \mathrm{m}^{3}$ in one aeration tank. Dynamic $\mathrm{O}_{2}$ dosage has the advantage that the $\mathrm{O}_{2}$ input can be minimized. It results in a lower total $\mathrm{N}_{\text {and }} \mathrm{NO}_{3}{ }^{-}$load but in turn, yields an increased $\mathrm{NH}_{4}{ }^{+}$load in the effluent [24]. In their work, Vanrolleghem and Gillot conclude that the dissolved $\mathrm{O}_{2}$ concentration should be controlled in every aeration tank as the performance, measured by the EQ improves significantly compared to the open-loop strategy [25]. Haemelick and colleagues evaluate different dissolved $\mathrm{O}_{2}$ operating conditions and identify the best option in which dissolved $\mathrm{O}_{2}$ is controlled in all aeration tanks with optimal concentrations of $1 \mathrm{gO}_{2} / \mathrm{m}^{3}$ each [26]. Yuan and colleagues simulate the treatment of synthetic domestic wastewater in a step-feed anaerobic-multiple anoxic/oxic-membrane bioreactor and find that a dissolved $\mathrm{O}_{2}$ concentration between 0.8 and $1.2 \mathrm{mgO}_{2} / \mathrm{L}$ is optimal for a high total $\mathrm{N}$-removal rate [27]. In addition to process parameters, such as the $\mathrm{O}_{2}$ concentration the composition of the wastewater itself, can also influence the cleaning performance. Low pollution loads of the wastewater due to mixing with rainwater, for example, can cause incomplete denitrification and can therefore worsen the N-performance [28,29].

Extended statistical entropy analysis (eSEA) is an evaluation method originally developed for the quantification of the concentration and dilution of chemical compounds caused by a process or system. It has been applied to a hypothetical crop farming region showing how the N-performance could be improved in terms of less dilution of $\mathrm{N}$-compounds to the environment [30]. In the following, eSEA has been used to assess the N-performance of Austrian farming regions, suggesting that statistical entropy has the potential to serve as an indicator for the evaluation of nutrient budgets [31]. Furthermore, eSEA has been applied to wastewater treatment plants (WWTPs) estimating the $\mathrm{N}$-removal performance. It has been shown that eSEA provides a more comprehensive assessment of the N-removal performance than the N-removal rate as, unlike the N-removal rate, it considers the distribution of all N-compounds in the different mass flows, such as the effluent, the sludge, and the off-gas [32]. In eSEA, all types of N-emissions, such as $\mathrm{NO}_{3}{ }^{-}, \mathrm{NO}_{2}{ }^{-}, \mathrm{NH}_{4}{ }^{+}$, and $\mathrm{N}_{\text {org }}$ in the effluent, $\mathrm{N}_{2}$ and $\mathrm{N}_{2} \mathrm{O}$ in the off-gas, and $\mathrm{N}_{\text {org }}$ in the sludge are differentiated and the dilution of the different $\mathrm{N}$-compounds in the river and the atmosphere is calculated based on the naturally occurring background concentrations of the particular N-compounds in the unstressed environment. The benefit of a particular WWTP is expressed as reduction in statistical entropy, $\Delta \mathrm{H}$, compared to the dilution of the $\mathrm{N}$-compounds after the direct discharge of the wastewater into the river. $\Delta \mathrm{H}$ ranges between $0 \%$ and $100 \%$. The higher $\Delta \mathrm{H}$ is the greater is the benefit of the particular WWT. Further processing of sludge has so far not been considered, however, it has been demonstrated that the transfer of $\mathrm{N}$ in sludge as part of the WWT process plays a positive role for the overall N-performance of the plant. 
Results from Austrian WWTPs reveal $\Delta \mathrm{H}$ reductions in the range of $73 \%$ to $86 \%$ for WWTPs operating according to state-of-the-art applying both nitrification and denitrification [32].

The purpose of this paper is to improve the assessment of the N-removal performance in the BSM No. 2 by implementing eSEA into the traditional EQ.

\section{Materials and Methods}

\subsection{The Simulation of WWT According to the BSM No. 2 Setup Including the Modeling of} GHG Emissions

Different WWT simulations are carried out based on the BSM No. 2 setup, published by Jeppsson and colleagues [1]. The model is coupled with the simulation of GHG emissions according to the model developed by Snip and colleagues [13]. The BSM No. 2 is operated with preceding denitrification. The anoxic tank volumes are $1500 \mathrm{~m}^{3}$ each and the aerated tank volumes are $3000 \mathrm{~m}^{3}$ each.

Three different wastewater types are used: the wastewater type I is the official dynamic influent file of the BSM No. 2 and the wastewater types II and III are constructed influent files, based on real data of WWTPs. The parameters characterizing the wastewater types and volumes that are relevant for the traditional EQ and eSEA are displayed in Table 1.

Table 1. Annual average influent data.

\begin{tabular}{|c|c|c|c|c|c|c|c|c|}
\hline \multirow{2}{*}{$\begin{array}{c}\text { Influent, } \\
\text { Wastewater } \\
\text { type }\end{array}$} & \multirow{2}{*}{$\begin{array}{c}\text { WW } \\
\text { inflow } \\
\mathbf{m}^{3} / \text { day } \\
\end{array}$} & \multicolumn{6}{|c|}{ Concentration in the wastewater } & \multirow[b]{2}{*}{$\begin{array}{c}\text { Total N-load } \\
\text { kgN/day }\end{array}$} \\
\hline & & $\begin{array}{l}\text { BOD } \\
\mathrm{g} / \mathbf{m}^{3}\end{array}$ & $\begin{array}{l}\text { COD } \\
\mathrm{g} / \mathrm{m}^{3}\end{array}$ & $\begin{array}{c}\mathrm{SS} \\
\mathrm{g} / \mathrm{m}^{3}\end{array}$ & $\begin{array}{c}\mathrm{NH}_{4}^{+} \\
\mathrm{g} \mathrm{N} / \mathrm{m}^{3}\end{array}$ & $\begin{array}{c}\text { SBN } \\
\text { g N/m } / \mathbf{m}^{3}\end{array}$ & $\begin{array}{c}\text { PBN } \\
\text { g N/m } \mathbf{m}^{3}\end{array}$ & \\
\hline I & 861 & 301 & 587 & 54.7 & 26.8 & 6.4 & 18.5 & 44.5 \\
\hline II & 864 & 274 & 524 & 151 & 35.3 & 2.52 & 2.52 & 34.9 \\
\hline III & 528 & 110 & 213 & 21.3 & 15.3 & 1.31 & 3.40 & 10.6 \\
\hline
\end{tabular}

Table 1 reveals that the wastewater types I and II have a similar flow rate. The wastewater type I shows a higher pollution load regarding total $\mathrm{N}$ but a different distribution of $\mathrm{NH}_{4}{ }^{+}, \mathrm{SBN}$, and $\mathrm{PBN}$ in the wastewater. Both the BOD and COD loads are slightly higher for the wastewater type I compared to the wastewater type II. The wastewater type II, in turn, has almost a three-fold higher SS-load compared to the wastewater type I. The wastewater type III represents a much diluted wastewater compared to the other wastewater types and has also a low flow rate.

The only operational parameter that is varied during the simulations is the $\mathrm{O}_{2}$ concentration in the three aeration tanks. The $\mathrm{O}_{2}$ concentration is varied because in this paper, we aim at obtaining significantly different N-removal performances to demonstrate the benefits of using eSEA for evaluation of the $\mathrm{N}$-removal performance over the traditional EQ. Literature findings show that the $\mathrm{O}_{2}$ concentration has a major influence on both the nitrification and denitrification. Table 2 summarizes the conditions of the realized simulations including the wastewater type used and the $\mathrm{O}_{2}$ concentration in the three aeration tanks.

Table 2 shows that the $\mathrm{O}_{2}$ concentration in the aeration tanks is controlled and varied from $1 \mathrm{mgO}_{2} / \mathrm{L}$ to $2 \mathrm{mgO}_{2} / \mathrm{L}$. This range has been chosen because former work has revealed that $\mathrm{O}_{2}$ concentrations below $1 \mathrm{mgO}_{2} / \mathrm{L}$ and above $3 \mathrm{mgO}_{2} / \mathrm{L}$ yield overall undesirable results. Sludge age is an important 
parameter, in particular for the nitrification process. For the Simulations, \#1, \#2, \#3, and \#4, the sludge age is 16 days, and for the Simulations \#5 and \#6 sludge age extends to 20 days. Hence, the sludge age in these simulations is more beneficial for the nitrification process compared to the other simulations.

Table 2. Summary of the performed wastewater treatment (WWT) simulations.

\begin{tabular}{ccccc}
\hline \multirow{2}{*}{ Simulation (\#) } & \multirow{2}{*}{ Influent, Wastewater type } & \multicolumn{3}{c}{ Aeration tank $\left(\mathbf{m g O}_{\mathbf{2}} / \mathbf{L}\right)$} \\
\cline { 3 - 5 } & \multirow{2}{*}{ I } & 1 & 2 & 3 \\
\hline 1 & & 2 & 2 & 1 \\
2 & II & 1 & 1 & 2 \\
3 & & 2 & 2 & 2 \\
4 & III & 1 & 1 & 1 \\
5 & & 2 & 2 & 2 \\
6 & &
\end{tabular}

Within the BSM No. 2 not all sorts of data are assessed that are necessary for eSEA. Therefore the amount of $\mathrm{N}_{2}$ due to denitrification is calculated based on the amount of the reacted $\mathrm{NO}_{3}{ }^{-}$in the anoxic tanks. For simplicity, it is assumed that all $\mathrm{N}^{-\mathrm{NO}_{3}}{ }^{-}$in the last anoxic tank minus the amount of $\mathrm{N}-\mathrm{N}_{2} \mathrm{O}$ is converted to $\mathrm{N}_{2}$ through the denitrification process. The $\mathrm{N}$-concentration in the sludge is finally calculated from the mass balance ( $\mathrm{N}$-input minus $\mathrm{N}$ in the effluent minus $\mathrm{N}$ in the off-gas).

Recent findings indicate that the aerobic nitrification process might be an even more dominant source for $\mathrm{N}_{2} \mathrm{O}$ production than the denitrification [16,33]. However, the emissions that can occur during the aerobic processes are not covered by the model used in this work and, therefore, the measured amounts of $\mathrm{N}_{2} \mathrm{O}$ are likely underestimated [13].

\subsection{Effluent Quality Index (EQ) Used in BSM No. 2}

The EQ describes the effluent quality by means of the indicators SS, COD, BOD, TKN, and $\mathrm{NO}_{3}{ }^{-}$ in the effluent in units of $\mathrm{kg}$ pollution (PU) per day.

$\mathrm{EQ}=\frac{1}{\left(\mathrm{t}_{2}-\mathrm{t}_{1}\right) * 1000} \int_{\mathrm{t}_{1}}^{\mathrm{t}_{2}}\left[\mathrm{~B}_{\mathrm{SS}} * \mathrm{SS}_{\mathrm{e}}(\mathrm{t})+\mathrm{B}_{\mathrm{COD}} * \mathrm{COD}_{\mathrm{e}}(\mathrm{t})+\mathrm{B}_{\mathrm{TKN}} * \mathrm{~S}_{\mathrm{TKN}, \mathrm{e}}(\mathrm{t})+\mathrm{B}_{\mathrm{NO}} * \mathrm{~S}_{\mathrm{NO}, \mathrm{e}}(\mathrm{t})+\mathrm{B}_{\mathrm{BOD} 5} * \mathrm{BOD}_{5, \mathrm{e}}(\mathrm{t})\right] * \mathrm{Q}_{\mathrm{e}}(\mathrm{t}) \mathrm{dt}$

$\left(\mathrm{t}_{2}-\mathrm{t}_{1}\right)$ : total evaluation period; $\mathrm{SS}$ in $\mathrm{gSS} / \mathrm{m}^{3}$; TKN $\left(\mathrm{SBN}+\mathrm{PBN}+\mathrm{NH}_{4}{ }^{+}\right)$in $\mathrm{gN} / \mathrm{m}^{3} ; \mathrm{NO}\left(\mathrm{NO}_{3}{ }^{7}\right)$ in $\mathrm{gN} / \mathrm{m}^{3}$; $\mathrm{BOD}_{5}$ : Biological $\mathrm{O}_{2}$ demand in 5 days in $\mathrm{gBOD} / \mathrm{m}^{3}$; $\mathrm{Q}_{\mathrm{e}}$ : Effluent in $\mathrm{m}^{3} /$ day; $\mathrm{B}$ : dimensionless weighting factors; initially: $\mathrm{B}_{\mathrm{SS}}=2 ; \mathrm{B}_{\mathrm{COD}}=1 ; \mathrm{B}_{\mathrm{TKN}}=20 ; \mathrm{B}_{\mathrm{NO}}=20 ; \mathrm{B}_{\mathrm{BOD} 5}=2$ [34]; in further work the weighting factors have been modified to: $\mathrm{B}_{\mathrm{SS}}=2 ; \mathrm{B}_{\mathrm{COD}}=1 ; \mathrm{B}_{\mathrm{TKN}}=30 ; \mathrm{B}_{\mathrm{NOx}}=10 ; \mathrm{B}_{\mathrm{BOD} 5}=2$ [24].

Originally, the same weighting factors were assigned to both $\mathrm{TKN}$ and $\mathrm{NO}_{3}{ }^{-}$, leading to the problem that a process control that achieves low concentrations of TKN in the effluent would not be rewarded. However, from an ecological point of view, low concentrations of TKN in the effluent are clearly preferential and, therefore, the weighting factors have been adapted accordingly $[1,24]$.

COD stands for all organic, particulate and soluble oxidable chemical compounds that might be more or less persistent in water, while BOD reflects the amount of organic compounds that will be broken down by organisms. Such compounds are, however, not further specified. SS can be especially dangerous to water bodies as they can carry pathogens on their surface. The particle size is, hereby, important as the total surface area per unit mass of particle increases with smaller particle size, and 
then the pollutant load can also increase. Although the COD, BOD, and SS are mostly removed from the wastewater, some amount of organic compounds and SS will still be discharged and eventually the low weighting factors will not reflect the toxicological potential appropriately [35]. The N-removal performance within the EQ is defined through the loads of both $\mathrm{TKN}$ and $\mathrm{NO}_{3}{ }^{-}$in the effluent. The latest weighting factors imply TKN to be three times more relevant to the receiving waters than $\mathrm{NO}_{3}{ }^{-}$, which is confirmed by the impact factors for aquatic eutrophication in various Life Cycle Impact Assessment methods [36-40]. However, the traditional EQ neither considers the difference of the environmental relevance between $\mathrm{NH}_{4}{ }^{+}, \mathrm{SBN}$, and $\mathrm{PBN}$, nor the impact of $\mathrm{N}_{2} \mathrm{O}$ on the atmosphere. The distribution of the $\mathrm{N}$ in the sludge is also excluded. The initial pollution load of the wastewater also does not play any role. Consequently, the cleaning performance of the WWT cannot be fully recompensed by the traditional EQ. A WWT system that, for example, emits less $\mathrm{N}_{2} \mathrm{O}$ to the atmosphere would not be rewarded by the traditional EQ compared to a WWT that generates high emissions of $\mathrm{N}_{2} \mathrm{O}$. Therefore, in Section 3.1, the traditional EQ is redefined.

\subsection{Extended Statistical Entropy Analysis (eSEA)}

\subsubsection{General Remarks}

The eSEA quantifies the concentration and dilution of chemical compounds caused by a process or a system [30]. The eSEA is a consequential extension of the SEA, which has been developed for assessment of dilution and concentration phenomena of chemical elements [41]. SEA is based on Shannon's definition of statistical entropy [42]. It quantifies the distribution of a substance among different mass flows and based on the change in the distribution states of the particular substance before and after a process (e.g., waste incineration or WWT) the concentration power respective the extent of dilution by the process is derived. The main advantage of eSEA, for evaluation of the N-removal performance of WWTPs, is that it allows a holistic assessment considering all $\mathrm{N}$-compounds that result from WWT including emissions in the effluent such as $\mathrm{NO}_{3}{ }^{-}, \mathrm{NO}_{2}{ }^{-}, \mathrm{NH}_{4}{ }^{+}$, $\mathrm{N}_{\text {org }}$, gaseous losses like $\mathrm{N}_{2}, \mathrm{~N}_{2} \mathrm{O}$ or $\mathrm{NH}_{3}$, and $\mathrm{N}$ in the sludge [32]. There is strong evidence that the environmental impact of substances diluted in the hydrosphere and atmosphere is reflected by their entropy production $[30,32,41,43,44]$. Another advantage of eSEA is that WWTPs, which achieve a cleaning performance below mandatory emission standards, will be rewarded. The main disadvantages of eSEA for the assessment of the N-removal performance are high data requirement, more complex calculation, and few applications for comparison of the results.

\subsubsection{Calculation Path}

Figure 1 describes how the WWT process can be described by statistical entropy. The left part of Figure 1a illustrates the N-budget of a typical WWTP applying both nitrification and denitrification. The right side of Figure 1a displays the reference situation for the calculation of eSEA, which is the direct discharge of the wastewater and therefore, of the initial N-load into the receiving waters. Figure 1b shows how statistical entropy reacts to both the WWT and the direct discharge of the wastewater to the river. 
Figure 1. (a) Left: Schematic illustration of N-compounds as occurring in the WWT process; Right: reference situation: wastewater is discharged untreated into the receiving waters; (b) Direct discharge of wastewater to the hydrosphere results in an entropy increase. WWT reduces the entropy, discharge of the effluent to the receiving water results in a (small) increase. $\Delta \mathrm{H}$ quantifies the cleaning performance of the WWT process.

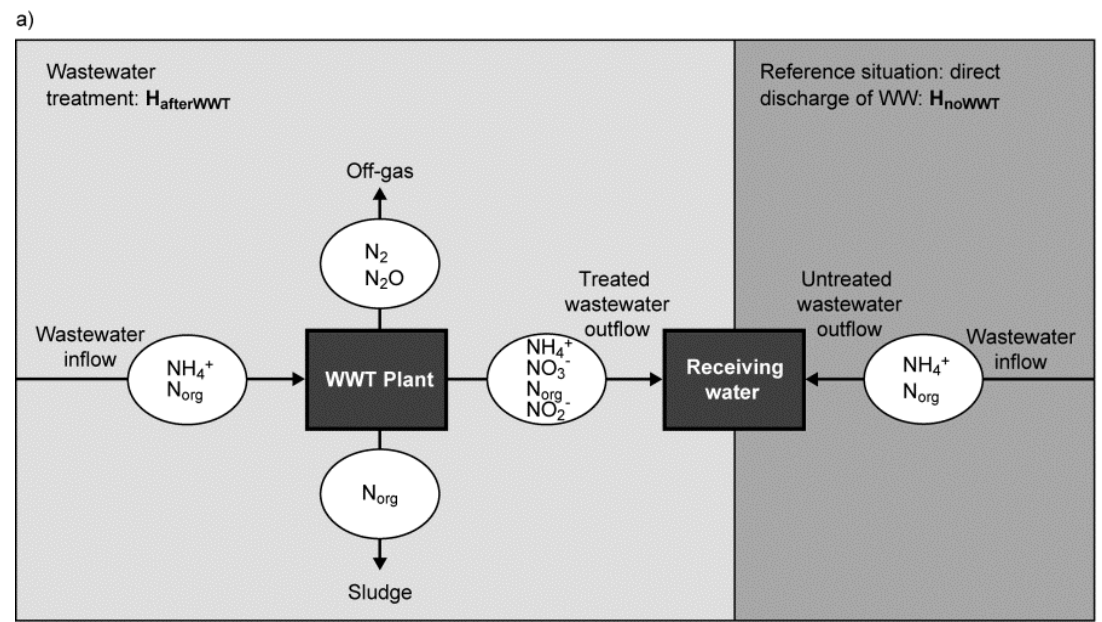

b)

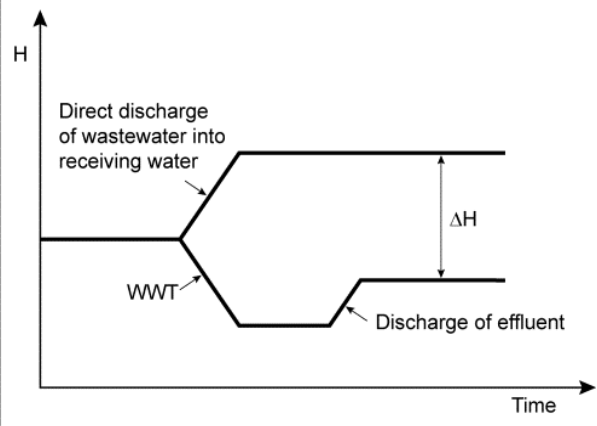

The N-compounds such as $\mathrm{NH}_{4}{ }^{+}, \mathrm{NO}_{3}{ }^{-}, \mathrm{NO}_{2}{ }^{-}, \mathrm{N}_{\text {org }}$, and $\mathrm{N}_{2} \mathrm{O}$ will be diluted up to the corresponding natural background concentrations in the river and the atmosphere, i.e., the concentrations present in the unstressed hydrosphere and atmosphere. For example, emission of $\mathrm{N}_{2}$ will not cause any dilution because the atmosphere mainly consists of $\mathrm{N}_{2}$. The transfer of $\mathrm{N}$ into the sludge (a concentration process) is considered but not possible dilution phenomena due to the following sludge management (e.g., combustion, land spreading). The following steps display the calculation of eSEA applied to N-compounds in WWT.

Step 1: measured data: $\dot{\mathrm{M}}_{\mathrm{i}}, \mathrm{c}_{\mathrm{im}}, \mathrm{c}_{\mathrm{im}, \mathrm{geog}}$;

Step 2: normalization of the mass flow:

$$
\begin{aligned}
\mathrm{m}_{i} & =\frac{\dot{\mathrm{M}}_{i}}{\sum_{i} \dot{\mathrm{X}}_{i m}} \\
\dot{\mathrm{X}}_{i m} & =\dot{\mathrm{M}}_{i} \times \mathrm{c}_{i m}
\end{aligned}
$$

Step 3: calculation of the diluting masses of each N-compound:

$$
\begin{gathered}
\mathrm{m}^{\prime}{ }_{i m}=\mathrm{m}_{i} \times \frac{\mathrm{c}_{i m}-c_{i m, g e o g}}{c_{i m, g e o g}}+\mathrm{m}_{i} \\
\mathrm{c}^{\prime}{ }_{i m}=\frac{\mathrm{c}_{i m} \times \mathrm{c}_{i m, g e o g}}{\mathrm{c}_{i m}-0.99 \times \mathrm{c}_{i m, g e o g}} \times 0.01
\end{gathered}
$$

Step 4: computation of the statistical entropy:

$$
\mathrm{H}\left(\mathrm{m}_{i m}^{\prime}, \mathrm{c}^{\prime}{ }_{i m}\right)=-\sum_{\mathrm{i}} \sum_{\mathrm{m}} \mathrm{m}^{\prime}{ }_{i m} \times \mathrm{c}^{\prime}{ }_{i m} \times \log _{2}\left(\mathrm{c}^{\prime}{ }_{i m}\right)
$$

$\dot{\mathrm{M}}_{i}$ is the measured mass flow in kg per day. The index, $i$, refers to the wastewater, effluent, off-gas, sludge, and the environmental compartment air and water. The variable $\mathrm{c}_{i m}$ (in $\mathrm{kgN} / \mathrm{kg}$ ) corresponds to the measured concentration of a $\mathrm{N}$-compound in the particular mass flow $i$. The $\mathrm{N}$-compounds $\left(\mathrm{NO}_{3}{ }^{-}\right.$, $\mathrm{NH}_{4}{ }^{+}$, etc.) are indexed by $m$. The background concentration of a compound $m$ in an environmental 
compartment $i$ is indicated by the variable $\mathrm{c}_{\text {im,geog. }}$. The mass flows are normalized according to Equation (2). The denominator of Equation (2) equals the total flow of N through the WWTP such that the masses $\mathrm{m}_{i}$ are related to one mass-unit of $\mathrm{N}$ (e.g., $\mathrm{kg}$ in the effluent per $\mathrm{kg}$ of the total $\mathrm{N}$ throughput). Normalization is required to make processes of different size comparable. In the next step, the diluting mass $\mathrm{m}_{i m}^{\prime}$ and the corresponding concentration term $\mathrm{c}_{i m}^{\prime}$ are calculated according to Equations (4) and (5), respectively. The mass-function calculates how much mass in the water or air is needed to dilute the emitted concentration to its corresponding background concentration. The dimensionless mass-function for the $\mathrm{N}$ in the sludge is computed according to Equation (2). The statistical entropy, $\mathrm{H}$, is then calculated according to Equation (6). Thus, the statistical entropy is a function of the mass flows, such as the wastewater, effluent, off-gas and sludge, the emission concentrations and the corresponding background concentrations of all N-compounds. More diluted mass flows and larger differences between the emitted and the background concentrations result in higher entropy values and, consequently, increased dilution in the environment. Given the assumption that for sustainable resource management dilution should be avoided whenever possible, low entropy values are desired. For a more detailed description of how to apply eSEA to processes, see [30]. Statistical entropy is calculated for the direct discharge of the wastewater to the receiving waters $\left(\mathrm{H}_{\text {nowwT }}\right)$ (Figure 1a right) and for the discharge of the treated wastewater including the N-transfer to the sludge and to the off-gas $\left(\mathrm{H}_{\text {afterwwT }}\right)$ ( $c f$. Figure 1a left). Both entropy values $\left(\mathrm{H}_{\text {nowwt }}\right.$ and $\mathrm{H}_{\text {afterWwT }}$ ) indicate the distribution of the different $\mathrm{N}$-compounds in the receiving water, the atmosphere, and the sludge. The difference between $\mathrm{H}_{\text {nowwT }}$ and $\mathrm{H}_{\text {afterwwt }}$ is the reduction in statistical entropy, $\Delta \mathrm{H}$, and equals the benefit of the particular WWTP. Figure $1 \mathrm{~b}$ highlights that WWT is certainly preferential to the direct discharge of the wastewater to the river because it will cause less dilution, which is expressed by less entropy production. The higher $\Delta \mathrm{H}$ is the greater is the benefit of the particular WWTP with respect to N-treatment. A detailed description of the calculation and the application of eSEA to WWTPs can be found in [30,32].

\section{Results and Discussion}

\subsection{The Implementation of eSEA as to the EQ}

In this section, eSEA is implemented into the traditional EQ leading to its redefinition. SS, COD, and BOD are collective indicators, including numerous chemical species that are not further specified (cf. Section 2.2). As a consequence, no data on losses of volatile organic compounds to the atmosphere are available thus preventing an accurate mass balance, which would be necessary for application of eSEA. Theoretically, SS, COD, and BOD could also be treated as single elements and SEA could then be used to quantify their concentration and dilution along the WWT process. However, the underlying processes for removal of $\mathrm{N}$-compounds, $\mathrm{COD}$, and BOD are interdependent, thus, demanding computation of a joint statistical entropy. At this stage, however, a joint SEA for a number of substances is not available and therefore, in this work we limit application of eSEA to N-compounds. In the first step the traditional EQ is broken down into the N-part and the remaining indicators of the effluent quality [Equations (7)-(9)].

$$
\mathrm{EQ}=\mathrm{EQ}_{\mathrm{N}}+\mathrm{EQ}_{\text {rest }}
$$


where

$$
\mathrm{EQ}_{\mathrm{N}}=\mathrm{EQ}_{\mathrm{TKN}}+\mathrm{EQ}_{\mathrm{NO}}
$$

and

$$
\mathrm{EQ}_{\mathrm{rest}}=\mathrm{EQ}_{\mathrm{SS}}+\mathrm{EQ}_{\mathrm{COD}}+\mathrm{EQ}_{\mathrm{BOD} 5}
$$

Next, $\mathrm{EQ}_{\mathrm{N}}$ is substituted by $\Delta \mathrm{H}$ and $\mathrm{EQ}_{\text {rest }}$ is analogously redefined as the reduction of $\mathrm{EQ}_{\text {rest }}$ compared to the direct discharge of the wastewater and thus the COD, BOD, and SS load to the receiving waters (Equations (10) and (11)).

$$
\Delta \mathrm{H}=\frac{\mathrm{H}_{\mathrm{N}, \text { noWWT }}-\mathrm{H}_{\mathrm{N}, \text { afterWWT }}}{\mathrm{H}_{\mathrm{N}, \text { noWWT }}} * 100
$$

and

$$
\Delta \mathrm{EQ}_{\text {rest }}=\frac{\mathrm{EQ}_{\text {rest,noWWT }}-\mathrm{EQ}_{\text {rest,afterWWT }}}{\mathrm{EQ}_{\text {rest, noWWT }}} * 100
$$

$\Delta \mathrm{EQ}_{\text {new }}$ is then defined as the weighted average of $\Delta \mathrm{H}$ and $\Delta \mathrm{EQ}_{\text {rest }}$ according to Equation (12). The modified EQ is assigned with a " $\Delta$ " to highlight that the new indicator of the cleaning performance represents a removal rate rather than pollution loads like in the traditional EQ. At this stage, the weighting of $\mathrm{N}$-compounds in comparison to the COD, BOD, and SS, as applied by Nopens and colleagues ( $c f$. Equation (1) in Section 2.2) is adopted resulting in final weighting of $\Delta \mathrm{H}$ [24].

$$
\Delta \mathrm{EQ}_{\text {new }}=\frac{12 * \Delta \mathrm{H}+\Delta \mathrm{EQ}_{\text {rest }}}{13}
$$

$\Delta \mathrm{EQ}_{\text {new }}$ is now expressed in $\%$ and ranges from $0 \%$ to $100 \%$. The higher the value for $\Delta \mathrm{EQ}$ new is the better is the entire cleaning performance of the WWT including $\mathrm{N}_{2} \mathrm{O}$ emissions.

\subsection{Comparison of the Traditional EQ and the New Defined EQ}

The cleaning performance of the realized WWT simulations is evaluated according to the traditional EQ (here: $E Q$ out $)$, the EQ removal rate $\left(\triangle \mathrm{EQ}\right.$, calculated from the reduction from $\mathrm{EQ}_{\mathrm{IN}}$ to EQouT, where $E Q_{I N}$ is the EQ from the untreated wastewater), the classical N-removal rate $(\Delta N$, the difference between the total $\mathrm{N}$ in the wastewater compared to the effluent), and the newly defined indicator, $\Delta \mathrm{EQ}_{\text {new. }} \Delta \mathrm{EQ}$ is additionally divided and presented for $\mathrm{N}\left(\Delta \mathrm{EQ} \mathrm{N}_{\mathrm{N}}\right)$ and $\mathrm{COD}, \mathrm{BOD}$, and $\mathrm{SS}\left(\Delta \mathrm{EQ} \mathrm{Q}_{\text {rest }}\right)$. The WWT simulations vary in the type and the amount of the wastewater and the alteration of the $\mathrm{O}_{2}$ concentration during the aerobic part of the biological treatment between $1 \mathrm{mg} / \mathrm{L}$ and $2 \mathrm{mg} / \mathrm{L}$. Simulations \#1, \#3, and \#5 are performed with $1 \mathrm{mgO}_{2} / \mathrm{L}$ while simulations \#2, \#4, and \#6 are carried out at a concentration of $2 \mathrm{mgO}_{2} / \mathrm{L}$ ( $c f$. Table 2, Section 2.1). Table 3 summarizes the simulated $\mathrm{N}_{2} \mathrm{O}$ emissions, the results for $\mathrm{EQ}_{\mathrm{IN}}, \mathrm{EQ}_{\mathrm{OUT}}, \Delta \mathrm{EQ}, \Delta \mathrm{EQ}_{\mathrm{rest}}, \Delta \mathrm{EQ}_{\mathrm{N}}, \Delta \mathrm{N}, \Delta \mathrm{H}$, and $\Delta \mathrm{EQ}_{\text {new }}$ for the usual evaluation period of one year.

Table 3 reveals that the pollution load in the effluent, indicated by EQout varies significantly from $1629 \mathrm{kgPU} /$ day to $5230 \mathrm{kgPU} /$ day. However, the EQ removal rates $(\Delta \mathrm{EQ})$ are less different ranging from $88 \%$ to $93 \%$. The EQ removal rates for $\mathrm{N}\left(\Delta \mathrm{EQ}_{\mathrm{N}}\right)$ are calculated between $86 \%$ and $93 \%$ and those for COD, BOD, and SS $\left(\Delta \mathrm{EQ}_{\text {rest }}\right)$ differ between $89 \%$ and $94 \%$. The N-removal rates $(\Delta \mathrm{N})$ 
vary between $67 \%$ and $88 \% . \Delta \mathrm{H}$ values are obtained between $66 \%$ and $81 \%$. These results are in accordance with the findings for Austrian WWTPs [32]. The simulated $\mathrm{N}_{2} \mathrm{O}$ emissions are found in the lower range $(0.35 \%-0.44 \%$ relative to the $\mathrm{N}$ feed in the wastewater; $c f$. Table 3$)$ among literature values [45]. $\Delta \mathrm{EQ}_{\text {new }}$ ranges between $68 \%$ and $82 \%$.

Table 3. $\mathrm{N}_{2} \mathrm{O}$ emissions, traditional effluent quality index (EQ) of the wastewater (EQ $\left.\mathrm{EN}_{\mathrm{N}}\right)$ and the effluent (EQout), EQ removal rate $(\triangle \mathrm{EQ})$, EQ removal rate for chemical oxygen demand (COD), biological oxygen demand (BOD), and suspended solids (SS) ( $\triangle \mathrm{EQ}$ rest), EQ removal rate for $\mathrm{N}(\Delta \mathrm{EQ})$, N-removal rate $(\Delta \mathrm{N}), \mathrm{N}$-removal performance according to extended statistical entropy analysis $(\mathrm{eSEA})(\Delta \mathrm{H})$, and the $\mathrm{EQ}_{\text {new }}$ for all WWT simulations.

\begin{tabular}{|c|c|c|c|c|c|c|c|c|c|c|}
\hline \multirow{2}{*}{$\begin{array}{c}\text { Simulation } \\
\#\end{array}$} & \multicolumn{2}{|c|}{$\mathrm{N}_{2} \mathrm{O}$} & \multirow{2}{*}{$\begin{array}{c}\mathrm{EQ}_{\mathrm{IN}} \\
\mathrm{kgPU} / \mathrm{day}\end{array}$} & \multirow{2}{*}{$\begin{array}{c}\text { EQ out } \\
\text { kgPU/day }\end{array}$} & \multirow{2}{*}{$\begin{array}{c}\Delta \mathbf{E Q} \\
\%\end{array}$} & \multirow{2}{*}{$\begin{array}{c}\Delta \mathbf{E} \mathbf{Q}_{\text {rest }} \\
\%\end{array}$} & \multirow{2}{*}{$\begin{array}{c}\Delta \mathbf{E} \mathbf{Q}_{\mathrm{N}} \\
\%\end{array}$} & \multirow{2}{*}{$\begin{array}{l}\Delta \mathrm{N} \\
\%\end{array}$} & \multirow{2}{*}{$\begin{array}{c}\Delta \mathbf{H} \\
\%\end{array}$} & \multirow{2}{*}{$\begin{array}{c}\Delta E Q_{\text {new }} \\
\%\end{array}$} \\
\hline & $\begin{array}{c}\mathrm{kgN}- \\
\mathrm{N}_{2} \mathrm{O} / \text { day } \\
\end{array}$ & $\% \mathbf{N}_{\text {IN }}$ & & & & & & & & \\
\hline 1 & 3.3 & 0.35 & \multirow{2}{*}{58,878} & 4,203 & 93 & 93 & 93 & 88 & 81 & 82 \\
\hline 2 & 3.2 & 0.34 & & 4,379 & 93 & 93 & 93 & 85 & 79 & 80 \\
\hline 3 & 3.7 & 0.44 & \multirow{2}{*}{53,571} & 4,682 & 91 & 94 & 88 & 74 & 71 & 73 \\
\hline 4 & 3.4 & 0.41 & & 5,230 & 90 & 94 & 86 & 67 & 66 & 68 \\
\hline 5 & 0.98 & 0.39 & \multirow{2}{*}{13,630} & 1,640 & 88 & 89 & 87 & 80 & 75 & 76 \\
\hline 6 & 0.94 & 0.37 & & 1,629 & 88 & 90 & 87 & 76 & 72 & 73 \\
\hline
\end{tabular}

Table 3 also shows that EQout, $\Delta \mathrm{N}, \Delta \mathrm{H}$, and $\Delta \mathrm{EQ}_{\text {new }}$ assess the simulations that were performed with $1 \mathrm{mgO}_{2} / \mathrm{L}$ as advantageous compared to those that were carried out with $2 \mathrm{mgO}_{2} / \mathrm{L}$ (lower EQout, higher $\Delta \mathrm{N}$, higher $\Delta \mathrm{H}$, and higher $\Delta \mathrm{EQ}_{\text {new }}$ ). Lower traditional EQ values at an $\mathrm{O}_{2}$ concentration of $1 \mathrm{mgO}_{2} / \mathrm{L}$ are in accordance with literature findings [24,26,27]. This effect is however not reflected by $\triangle \mathrm{EQ}_{\mathrm{N}}$ or $\triangle \mathrm{EQ} . \mathrm{N}_{2} \mathrm{O}$ emissions are slightly lower at an $\mathrm{O}_{2}$ set point of $2 \mathrm{mgO}_{2} / \mathrm{L}$ than at $1 \mathrm{mgO}_{2} / \mathrm{L}$. This also validates the findings in literature $[4,12,13]$. The faintly altered $\mathrm{N}_{2} \mathrm{O}$ emissions, however, hardly affect the overall $\mathrm{N}$-removal performance measured by $\Delta \mathrm{H}$, which puts the relevance of $\mathrm{N}_{2} \mathrm{O}$ for the overall N-removal performance somehow in perspective. A more detailed investigation of the influence of $\mathrm{N}_{2} \mathrm{O}$ for the overall $\mathrm{N}$-removal performance according to eSEA is additionally discussed in Section 3.3. Note that the simulation of $\mathrm{N}_{2} \mathrm{O}$ emissions as performed in this work only considers the $\mathrm{N}_{2} \mathrm{O}$ from the denitrification process, disregarding the emissions from the nitrification process. Thus, the $\mathrm{N}_{2} \mathrm{O}$ emissions are likely underestimated.

The aim of this paper is to improve evaluation of the N-removal performance within the BSM No. 2 by implementing eSEA into the traditional EQ. Therefore, in Figure 2, the entropy based indicator is discussed in comparison to the N-removal performance according to the EQ removal rate for $N, \Delta \mathrm{EQ}_{\mathrm{N}}$, and the classical N-removal rate, $\Delta \mathrm{N}$.

Figure 2 shows that the Simulations \#1, \#3, and \#5, which are performed with an $\mathrm{O}_{2}$ concentration of $1 \mathrm{mgO}_{2} / \mathrm{L}$ show higher N-removal rates and higher $\Delta \mathrm{H}$ values compared to the Simulations \#2, \#4, and \#6, which are carried out at a concentration of $2 \mathrm{mgO}_{2} / \mathrm{L} . \Delta \mathrm{EQ}_{\mathrm{N}}$ in turn, does not show this trend: $\triangle \mathrm{EQ}_{\mathrm{N}}$ is the same for the Simulations \#1 and \#2 (93\%), as well as for the Simulations \#5 and \#6 (87\%). It is slightly higher for the Simulation \#3 (88\%) compared to the value for the Simulation \#4 $(86 \%)$. To understand the differences in the N-removal performance between $\Delta E Q_{N}, \Delta N$, and $\Delta H$ we must on one hand consider the N-loads in the wastewater and the effluent and on the other hand the 
distribution of the particular N-compounds in the wastewater, the effluent, the off-gas, and the sludge. $\mathrm{N}_{2}$ in the off-gas does not contribute to statistical entropy because it is received by the atmosphere with a natural $\mathrm{N}_{2}$ background concentration of approximately $75 \%$. The differences between $\mathrm{N}_{2} \mathrm{O}$ emissions of different simulations are small compared to the other $\mathrm{N}$-emissions and therefore have only a small contribution to statistical entropy ( $c f$. Table 3 ). The extent of statistical entropy produced due to the transfer of $\mathrm{N}_{\text {org }}$ to the sludge is comparable for all six simulations (not shown here numerically). Hence, the differences in the effluent are the main responsible factors affecting the N-removal performance assessed by eSEA. The concentrations and loads of the N-compounds in the different wastewater types can be found in Table 1, in Section 2.1. The loads of the relevant N-compounds in the effluent are shown in Table 4.

Figure 2. EQ removal rate for $\mathrm{N}\left(\Delta \mathrm{EQ} \mathrm{Q}_{\mathrm{N}}\right), \mathrm{N}$-removal rate $(\Delta \mathrm{N})$, and the N-removal performance according to $\operatorname{eSEA}(\Delta \mathrm{H})$ for all WWT simulations.

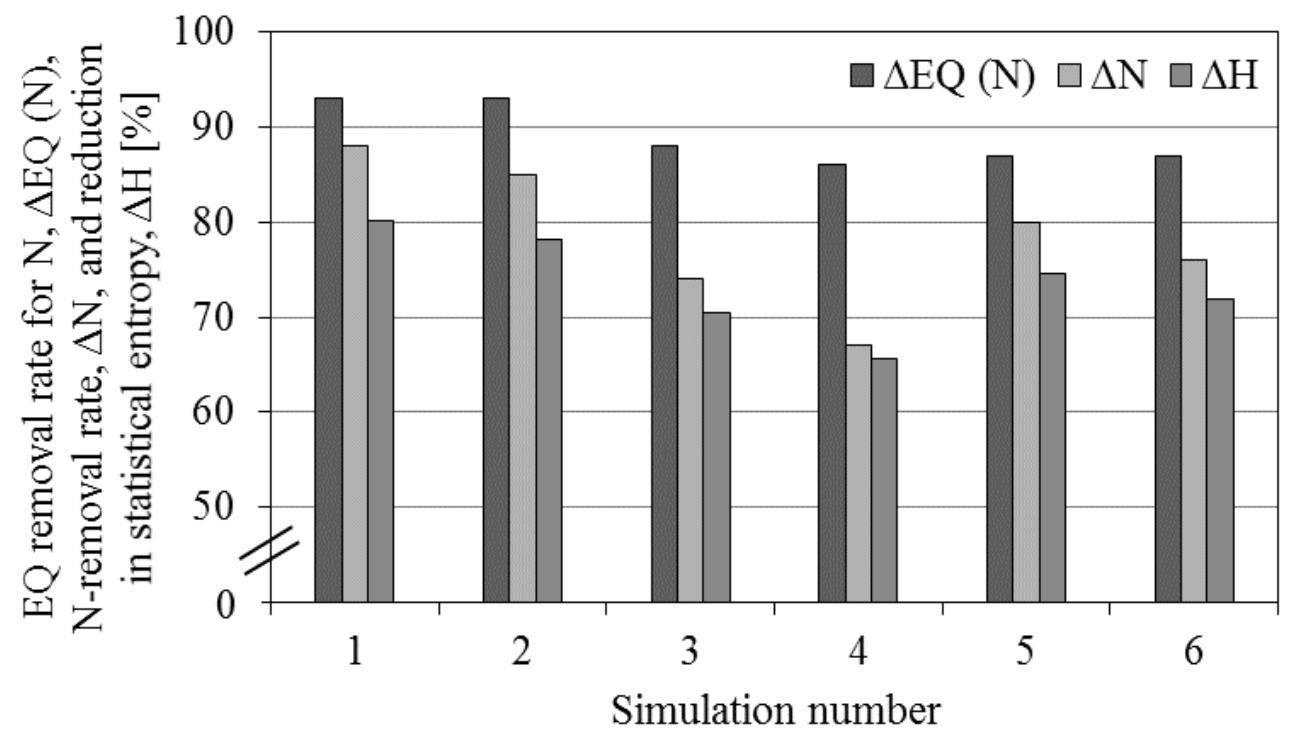

Table 4. Loads of the different N-compounds in the effluent for all simulations performed.

\begin{tabular}{ccccccc}
\hline \multirow{2}{*}{ N-compound } & \multicolumn{7}{c}{ Load $(\mathbf{k g N} /$ day) for Simulation \# } \\
\cline { 2 - 7 } & $\mathbf{1}$ & $\mathbf{2}$ & $\mathbf{3}$ & $\mathbf{4}$ & $\mathbf{5}$ & $\mathbf{6}$ \\
\hline $\mathrm{N}^{-N N_{3}{ }^{-}}$ & 3.7 & 4.8 & 7.2 & 10 & 1.1 & 1.8 \\
$\mathrm{~N}^{-} \mathrm{NH}_{4}{ }^{-}$ & 0.17 & $8.7 \times 10^{-2}$ & 0.31 & 0.16 & 0.45 & 0.21 \\
$\mathrm{SBN}$ & 1.7 & 1.6 & 1.6 & 1.5 & 0.59 & 0.58 \\
$\mathrm{PBN}$ & $2.6 \times 10^{-2}$ & $2.6 \times 10^{-2}$ & $2.6 \times 10^{-2}$ & $2.6 \times 10^{-2}$ & $5.3 \times 10^{-3}$ & $4.7 \times 10^{-3}$ \\
$\mathrm{TKN}$ & 1.9 & 1.8 & 1.7 & 1.9 & 1.1 & 0.8 \\
\hline
\end{tabular}

Table 4 demonstrates that the loads of SBN and PBN are not affected by a change of the $\mathrm{O}_{2}$ concentration from $1 \mathrm{mgO}_{2} / \mathrm{L}$ to $2 \mathrm{mgO}_{2} / \mathrm{L}$. The main differences are found between the loads of $\mathrm{N}-\mathrm{NO}_{3}{ }^{-}$and $\mathrm{N}-\mathrm{NH}_{4}{ }^{+}$. The Simulations \#1, \#3, and \#5 lead to a lower $\mathrm{N}^{-\mathrm{NO}_{3}}{ }^{-}$and to a higher $\mathrm{N}_{-} \mathrm{NH}_{4}{ }^{+}$ load in the effluent compared to the Simulations \#2, \#4, and \#6. This result is comprehensible because the nitrification process that converts $\mathrm{NH}_{4}{ }^{+}$to $\mathrm{NO}_{3}{ }^{-}$depends upon presence of $\mathrm{O}_{2}$ and the denitrification process depends on absence of soluble $\mathrm{O}_{2}$. Less $\mathrm{O}_{2}$ available thus means a discrimination of nitrification against denitrification and finally more $\mathrm{NH}_{4}{ }^{+}$and less $\mathrm{NO}_{3}{ }^{-}$. The $\Delta \mathrm{EQ} \mathrm{N}$ values are almost identical for 
the Simulations \#3 to \#6 although the $\Delta \mathrm{N}$ and the $\Delta \mathrm{H}$ values as well as the emission loads of $\mathrm{NO}_{3}{ }^{-}$and $\mathrm{NH}_{4}{ }^{+}$in the effluent differ considerably ( $c f$. Table 3 and Figure 3). The only methodical difference between the indicators $\mathrm{N}$-removal rate, $\Delta \mathrm{N}$, and the $\mathrm{EQ}$ removal rate for $\mathrm{N}, \Delta \mathrm{EQ}_{\mathrm{N}}$, is that $\Delta \mathrm{EQ}_{\mathrm{N}}$ differentiates between $\mathrm{TKN}$ and $\mathrm{NO}_{3}{ }^{-}$by applying different weighting factors (cf. Equation (1) in Section 2.2). The weighting factors for COD, BOD, SS, and $\mathrm{N}$ were initially derived based on discharge permits for Denmark and Flanders [34]. However, $\mathrm{TKN}$ and $\mathrm{NO}_{3}{ }^{-}$had the same weighting factor $\left[\mathrm{B}_{\mathrm{TKN}}=\mathrm{B}_{\mathrm{NO}^{-}}=20\right.$, cf. Equation (1) in Section 2.2] and were later adapted to $\mathrm{B}_{\mathrm{TKN}}=30$ and $\mathrm{B}_{\mathrm{NO} 3^{-}}=10$ for better agreement with ecological aspects [24]. The weighting factors are, thus, based on experts' assessment of the harming potential of $\mathrm{TKN}$ and $\mathrm{NO}_{3}{ }^{-}$and can be questioned.

In eSEA all $\mathrm{N}$-compounds are differentiated based on the corresponding natural background concentrations of the particular N-compounds in the unstressed environment [30,32]. The eSEA distinguishes the $\mathrm{N}$-compounds based on a naturally existing relationship and thus offers a reasonable alternative to the weighting factors in the EQ. The concentrations of the particular N-compounds in the effluent and the corresponding natural background concentrations are displayed in Table 5.

Table 5. Concentrations of the different N-compounds in the effluent for all simulations performed and the naturally occurring background concentrations of the particular $\mathrm{N}$-compounds in rivers.

\begin{tabular}{|c|c|c|c|c|c|c|c|}
\hline \multirow{2}{*}{ N-compound } & \multicolumn{6}{|c|}{ Concentration $\left(\mathrm{gN} / \mathrm{m}^{3}\right)$ for Simulation \# } & \multirow{2}{*}{$\begin{array}{l}\text { Natural background } \\
\text { concentration }\end{array}$} \\
\hline & 1 & 2 & 3 & 4 & 5 & 6 & \\
\hline $\mathrm{N}^{-\mathrm{NO}_{3}}{ }^{-}$ & 4.3 & 5.6 & 8.3 & 12 & 2.0 & 3.4 & $1.0-4.0^{(1)}$ \\
\hline $\mathrm{N}-\mathrm{NH}_{4}^{+}$ & 0.20 & 0.10 & 0.36 & 0.18 & 0.85 & 0.40 & $0.01-0.05^{(2)}$ \\
\hline SBN & 1.9 & 1.89 & 1.8 & 1.8 & 1.1 & 1.1 & $0.1-0.4^{(2)}$ \\
\hline PBN & $3.0 \times 10^{-2}$ & $3.0 \times 10^{-2}$ & $3.0 \times 10^{-2}$ & $3.0 \times 10^{-2}$ & $1 \times 10^{-2}$ & $1 \times 10^{-2}$ & $0.1-0.4^{(2)}$ \\
\hline TKN & 2.2 & 2.0 & 2.2 & 2.0 & 2.0 & 1.5 & - \\
\hline
\end{tabular}

Table 5 shows a range of naturally occurring background concentrations for $\mathrm{NO}_{3}{ }^{-}, \mathrm{NH}_{4}{ }^{+}, \mathrm{SBN}$, and PBN. According to the Austrian Water Act, rivers of very good and good water quality can contain $\mathrm{NO}_{3}{ }^{-}$ between $1 \mathrm{mgN} / \mathrm{L}$ and $4 \mathrm{mgN} / \mathrm{L}$ [46]. Furthermore, according to the Austrian Water Act a dissolved organic carbon (DOC) concentration of $1 \mathrm{mg} / \mathrm{L}$ to $4 \mathrm{mg} / \mathrm{L}$ represents rivers with a very good and good water quality, depending on the hydro-geological conditions. Assuming a $\mathrm{C} / \mathrm{N}$ ratio of 10 to 1 , SBN concentrations between $0.1 \mathrm{mgN} / \mathrm{L}$ and $0.4 \mathrm{mgN} / \mathrm{L}$ can be expected. PBN concentrations are likely to be found in the same range as for SBN since particulate organic matter is always present in rivers. The $\mathrm{NH}_{4}{ }^{+}$background concentration is set between $0.01 \mathrm{mgN} / \mathrm{L}$ and $0.05 \mathrm{mgN} / \mathrm{L}$, which is considered as reasonable. For calculation of eSEA in this work, the lower values of the background concentrations presented in Table 4 are used. Note that the $\Delta H$ values would increase if the upper values for the

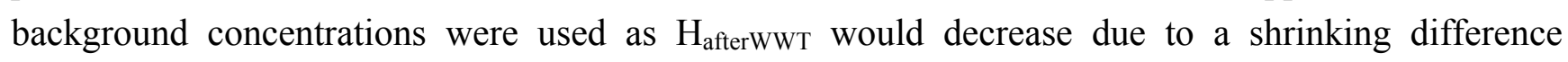
between the emission concentrations and the background concentrations (cf. Figure 1). However, for the simulations presented in this work the $\Delta \mathrm{H}$ values would change only marginally (not shown here numerically) as the ranges for the background concentrations are rather narrow.

Generally, $\mathrm{N}_{-} \mathrm{NH}_{4}{ }^{+}$has a higher environmental impact on water bodies than the same amount of $\mathrm{N}-\mathrm{NO}_{3}{ }^{-}[36,38]$. Discharge of a certain amount of $\mathrm{N}^{-} \mathrm{NH}_{4}{ }^{+}$would, in fact, generate more entropy 
than the same amount of ${\mathrm{N}-\mathrm{NO}_{3}}^{-}$because the natural background concentration of $\mathrm{N}^{-\mathrm{NH}_{4}}{ }^{+}$is approximately two orders of magnitude lower than that of $\mathrm{N}^{-\mathrm{NO}_{3}}{ }^{-}$( $c f$. Table 5). However, the emission of, for example, double the $\mathrm{NH}_{4}{ }^{+}$concentration will not generate double the entropy because for calculation of eSEA logarithmic functions are used [30]. Such logarithmic trend can also be found for determination of ecotoxicological effects [47-53]. In the simulations presented in this work the $\mathrm{N}-\mathrm{NO}_{3}{ }^{-}$concentrations are significantly higher than those for $\mathrm{N}_{-} \mathrm{NH}_{4}{ }^{+}$(cf. Table 5). The higher $\mathrm{NO}_{3}{ }^{-}$ emissions in the Simulations \#2, \#4, and \#6 therefore generate more entropy than the elevated $\mathrm{NH}_{4}{ }^{+}$

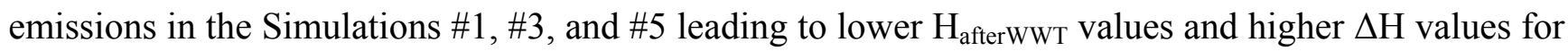
the Simulations \#1, \#3, and \#5.

Note that the wastewater and effluent flow rates and the concentrations of COD, BOD, SS, and the individual $\mathrm{N}$-compounds vary over the entire evaluation period of one year. For example, for Simulation \#1 the average value for $\mathrm{NO}_{3}{ }^{-}$within the entire evaluation period is $7.59 \mathrm{gN} / \mathrm{m}^{3} \pm 23 \%$ but it can vary $\pm 100 \%$ for $\mathrm{NH}_{4}{ }^{+}$, for instance. As in this work we use the average values of the entire evaluation period the fluctuations of the cleaning, performance are not addressed. Principally, the calculation of eSEA could be implemented into the BSM No. 2 and computed for every time step. That way, the variation in the cleaning performance could be displayed for the entire evaluation period.

\subsection{Scenario Analysis: Relevance of $\mathrm{N}_{2} \mathrm{O}$ for the Overall $\mathrm{N}$-Performance}

In this section the influence of $\mathrm{N}_{2} \mathrm{O}$ emissions to the overall performance of the WWT is investigated in more detail. For this purpose the $\mathrm{N}_{2} \mathrm{O}$ emissions of Simulation \#1 are varied between $0 \%$ of the $\mathrm{N}$ in the wastewater $\left(\mathrm{N}_{\mathrm{IN}}\right)$ and $10 \% \mathrm{~N}_{\mathrm{IN}}\left(3.95 \mathrm{kgN}-\mathrm{N}_{2} \mathrm{O} /\right.$ day). This covers a wide range of realistically expectable $\mathrm{N}_{2} \mathrm{O}$ emissions [4]. Figure 3 shows how the $\mathrm{N}_{2} \mathrm{O}$ emissions influence $\Delta \mathrm{H}$ and in consequence $\Delta \mathrm{EQ}_{\text {new }}$. Note that neither $\triangle \mathrm{EQ}_{\mathrm{N}}$ nor the traditional EQ would be affected by a variation of $\mathrm{N}_{2} \mathrm{O}$ emissions at all because they only consider the compounds in the effluent.

Figure 3 shows that both $\Delta \mathrm{H}$ and $\Delta \mathrm{EQ}_{\text {new }}$ decrease with increasing $\mathrm{N}_{2} \mathrm{O}$ emissions (deterioration of both the $\mathrm{N}$-removal performance and the entire cleaning performance). $\Delta \mathrm{EQ}_{\text {new }}$ reacts less strongly (marginally smaller slope) to a change of the $\mathrm{N}_{2} \mathrm{O}$ emissions compared to $\Delta \mathrm{H}$ (cf. Figure 3 ) as it also considers the parameters $\mathrm{COD}, \mathrm{BOD}$, and $\mathrm{SS}$ and these are not affected by an alteration of $\mathrm{N}_{2} \mathrm{O}$ emissions. Figure 3 also reveals that the contribution of $\mathrm{N}_{2} \mathrm{O}$ emissions to the overall $\mathrm{N}$-removal performance is rather low: $\Delta \mathrm{H}$ ranges between $80 \%$ for $0 \% \mathrm{~N}_{-} \mathrm{N}_{2} \mathrm{O}$ relative to $\mathrm{N}_{\mathrm{IN}}$ and $77 \%$ for $10 \%$ $\mathrm{N}-\mathrm{N}_{2} \mathrm{O}$ relative to $\mathrm{N}_{\mathrm{IN}}$ and $\Delta \mathrm{EQ}$ new ranges between $81 \%$ for $0 \% \mathrm{~N}-\mathrm{N}_{2} \mathrm{O}$ relative to $\mathrm{N}_{\mathrm{IN}}$ and $78 \%$ for $10 \% \mathrm{~N}-\mathrm{N}_{2} \mathrm{O}$ relative to $\mathrm{N}_{\mathrm{IN}}$. The reason, therefore, is that very low amounts of $\mathrm{N}_{2} \mathrm{O}$ are actually emitted ( $c f$. Table 3). The use of eSEA and the redefinition of the traditional EQ to $\triangle \mathrm{EQ}$ new provide the possibility of integrating $\mathrm{N}_{2} \mathrm{O}$ emissions into the overall cleaning performance of a WWTP and therewith balance the effluent quality and the GHG criteria. Another advantage of applying eSEA is that arbitrary weighting of the several N-compounds can be avoided. However, two arguable points remain within the $\triangle \mathrm{EQ}_{\text {new }}$ : first, the N-removal performance is still weighted compared to the COD, BOD, and SS based on experts' knowledge adopted from Nopens and colleagues [24]. Ideally, the N-removal performance would be coupled with the removal performance for COD, BOD, and SS without application of arbitrary weighting factors. One possibility to avoid such weighting could be to perform a common eSEA for N, COD, BOD, and SS. For this purpose eSEA would need to be 
extended to multiple "substances families" (e.g., nutrients, carbon), which remains an issue for future research. Second, the weighting factor currently applied is questionable with regards to $\mathrm{N}_{2} \mathrm{O}$ and its severe GHG potential. On one hand, it can be argued that the small impact of $\mathrm{N}_{2} \mathrm{O}$ on the overall $\mathrm{N}$-removal performance is reasonable given the low amounts of $\mathrm{N}_{2} \mathrm{O}$ produced by the simulated WWT in this work. On the other hand, this can put us at risk to underestimate this GHG potential. If, however, a weighting factor is to be applied that gives credit to the $\mathrm{GHG}$ potential of $\mathrm{N}_{2} \mathrm{O}$ it should in either case be chosen carefully in order not to diminish the relevance of nitrification and denitrification to protect water bodies from discharge of harmful $\mathrm{N}$-compounds.

Figure 3. Effect of $\mathrm{N}_{2} \mathrm{O}$-emissions on the $\mathrm{N}$-removal performance measured by $\triangle E \mathrm{Q}_{\mathrm{N}}$ and $\Delta \mathrm{H}$ and on the entire cleaning performance according to both $\triangle \mathrm{EQ}$ and $\mathrm{EQ}_{\text {new. }}$

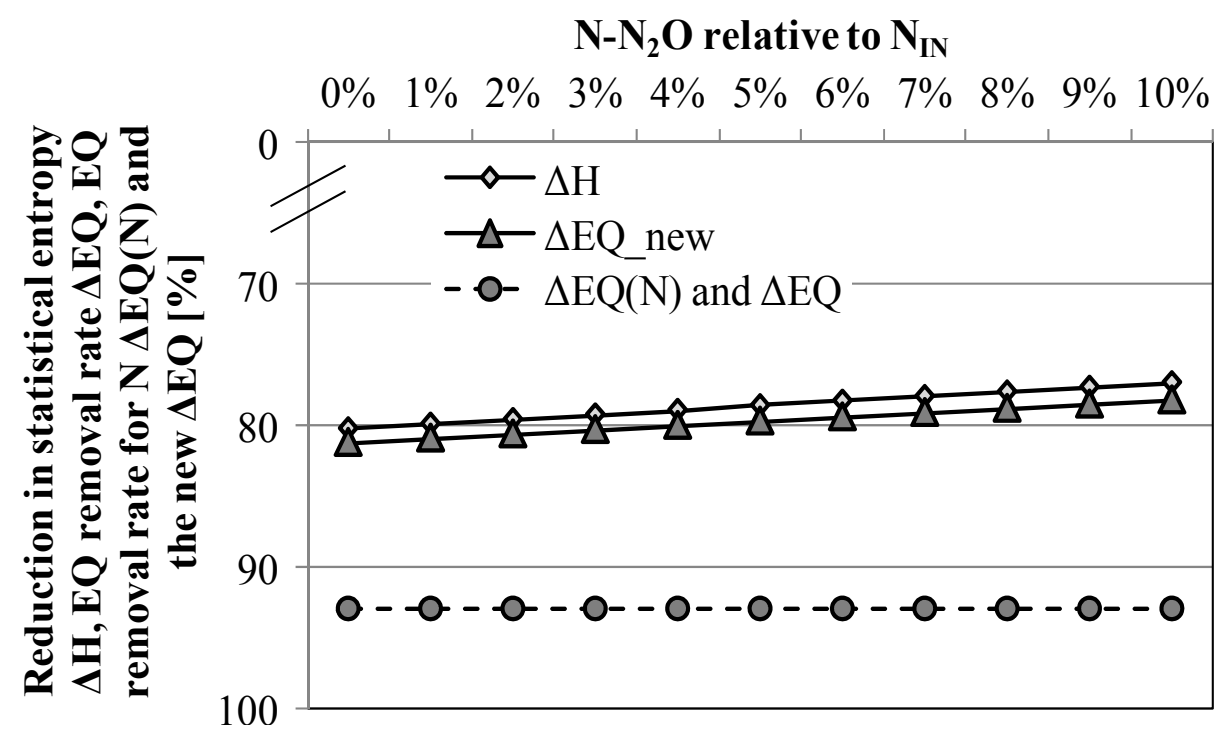

\section{Conclusions}

This paper uses eSEA for evaluation of the N-removal performance of WWT and implements the entropy indicator into the traditional EQ as it is applied in the BSM No. 2 software by redefining the traditional EQ to $\triangle E Q_{\text {new. }}$. The main benefits of eSEA are first, that use of weighting factors based on experts' estimation of the harming potential of the different $\mathrm{N}$-compounds can be avoided as the several N-compounds in eSEA are distinguished based on their naturally occurring background concentrations in the unstressed hydrosphere and atmosphere. Second, in eSEA, N-compounds such as $\mathrm{NH}_{4}{ }^{+}, \mathrm{SBN}$, and PBN can be differentiated. Nitrite, $\mathrm{NO}_{2}{ }^{-}$, a byproduct of the nitrification process could principally also be included and emissions of $\mathrm{N}_{2} \mathrm{O}$ can be considered for a more comprehensive assessment of the N-removal performance. Thus, the effluent quality is balanced with the $\mathrm{GHG}_{2} \mathrm{O}$ in the context of the overall cleaning performance. The newly defined parameter, $\Delta \mathrm{EQ} \mathrm{Q}_{\text {new }}$, thus, allows a more comprehensive and therefore, a more precise evaluation of the WWT performance by considering the characteristics of the wastewater and the distribution of all N-compounds in the effluent, the off-gas, and the sludge. However, the problem of using arbitrary weighting factors could not be solved in this work so that the N-removal performance is still weighted against the removal performance for COD, BOD, and SS, based on the weighting factors originally applied in the traditional EQ. The calculation of eSEA can easily be modeled within the BSM No. 2. That way, the 
cleaning performance expressed by $\Delta \mathrm{EQ}_{\text {new }}$ can be provided for every time step and reflect the fluctuations within the evaluation period. This work also demonstrates that realistically expectable $\mathrm{N}_{2} \mathrm{O}$ emissions have only a moderate influence on the overall cleaning performance. However, as already recommended by other researchers (Corominas et al., 2012, [15]), a more detailed model for the estimation of $\mathrm{N}_{2} \mathrm{O}$ emissions is required to predict the $\mathrm{N}_{2} \mathrm{O}$ production during the entire WWT process more realistically. Furthermore, it remains unclear if the $\mathrm{GHG}$ potential of $\mathrm{N}_{2} \mathrm{O}$ is adequately represented by the $\Delta \mathrm{EQ}_{\text {new. }}$.

\section{Acknowledgments}

We acknowledge financial support from the Austrian Science Funds (FWF) as part of the Vienna Doctoral Programme on Water Resource Systems (DK-plus W1219-N22). The authors wish to thank the managers of Sha'Tin WWTP (Hong Kong) and of Epinal (France) WWTP for providing wastewater data. The financial support of the PROCORE program (2006-2007) is also acknowledged.

\section{Conflicts of Interest}

The authors declare no conflict of interest.

\section{References}

1. Jeppsson, U.; Pons, M.-N.; Nopens, I.; Alex, J.; Copp, J.B.; Gernaey, K.V.; Rosen, C.; Steyer, J.-P.; Vanrollehghem, P.A. Benchmark simulation model No. 2: General protocol and exploratory case studies. Water Sci. Technol. 2007, 56, 67-78.

2. IPCC. Climate Change 2001: The Scientific Basis. In Atmosferic Chemistry and Greenhouse Gases; UNEP GRID-Ardenal: Ardenal, Norway 2001; Chapter 4.

3. Gupta, D.; Singh, S.K. Greenhouse gas emissions from wastewater treatment plants: A case study of noida. J. Water Sustain. 2012, 2, 131-139.

4. Kampschreur, M.J.; Temmink, H.; Kleerebezem, R.; Jetten, M.S.M.; van Loosdrecht, M.C.M. Nitrous oxide emission during wastewater treatment. Water Res. 2009, 43, 4093-4103.

5. Lolito, A.M.; Wunderlin, P.; Joss, A.; Kipf, M.; Siegrist, H. Nitrous oxide emissions from the oxidation tank of a pilot activated sludge plant. Water Res. 2012, 46, 3563-3573.

6. Goreau, T.J.; Kaplan, W.A.; Wofsy, S.C.; McElroy, M.B.; Valois, F.W.; Watson, S.W. Production of nitrite and nitrogen oxide $\left(\mathrm{N}_{2} \mathrm{O}\right)$ by nitrifying bacteria at reduced concentrations of oxygen. Appl. Environ. Microbiol. 1980, 40, 526-532.

7. Dumit, M.; Gabarro, J.; Murthy, S.; Riffat, R.; Wett, B.; Colprim, J.; Chandran, K. The Impact of Post Anoxic Dissolved Oxygen Concentrations on Nitrous Oxide Emissions in Nitrification Processes. In Proceedings of the 84th Annual Water Environment Federation Technical Exhibition and Conference, Los Angeles, CA, USA, 15-19 October 2011; Water Environment Federation: Alexandria, VA, USA, 2011.

8. Hu, Z.; Zhang, J.; Xie, H.; Li, S.; Wang, J.; Zhang, T. Effect of anoxic/aerobic phase fraction on $\mathrm{N}_{2} \mathrm{O}$ emission in a sequencing batch reactor under low temperature. Bioresour. Technol. 2011, $102,5486-5491$. 
9. Aboobakar, A.; Cartmell, E.; Stephenson, T.; Jones, M.; Vale, P.; Dotro, G. Nitrous oxide emissions and dissolved oxygen profiling in a full-scale nitrifying activated sludge treatment plant. Water Res. 2012, 47, 524-534.

10. Winter, P.; Pearce, P.; Colquhoun, K. Contributions of nitrous oxide emissions form wastewater treatment to carbon accounting. J. Water Clim. Chang. 2012, 3, 95-109.

11. Jia, W.; Liang, S.; Zhang, J.; Ngo, H.H.; Guo, W.; Yan, Y.; Zou, Y. Nitrous oxide emission in low-oxygen simultaneous nitrification and denitrification process: Sources and mechanisms. Bioresour. Technol. 2013, doi:10.1016/j.biortech.2013.02.117.

12. Flores-Alsina, X.; Corominas, L.; Snip, L.; Vanrolleghem, P.A. Including greenhouse gas emissions during benchmarking of wastewater treatment plant control strategies. Water Res. 2011, 45, 4700-4710.

13. Snip, L. Quantifying the Greenhouse Gas Emissions of Wastewater Treatment Plants. Master's Thesis, Department of Agrotechnology and Food Science, Wageningen University, Wageningen, The Netherland, 2010.

14. Rodriguez-Garcia, G.; Hospido, A.; Bagley, D.M.; Moreira, M.T.; Feijoo, G. A methodology to estimate greenhouse gases emissions in Life Cycle Inventories of wastewater treatment plants. Environ. Impact Assess. Rev. 2012, 37, 37-46.

15. Corominas, L.; Flores-Alsina, X.; Snip, L.; Vanrolleghem, P.A. Comparison of different modeling approaches to better evaluate greenhouse gas emissions from whole wastewater treatment plants. Biotechnol. Bioeng. 2012, doi:10.1002/bit.24544.

16. Yu, R.; Kampschreur, M.J.; van Loosdrecht, M.C.M.; Chandran, K. Mechanisms and specific directionality of autotrophic nitrous oxide and nitric oxide generation during transient anoxia. Environ. Sci. Technol. 2010, 44, 1313-1319.

17. Wunderlin, P.; Lehmann, M.F.; Siegrist, H.; Tuzson, B.; Joss, A.; Emmenegger, L.; Mohn, J. Isotope signatures of $\mathrm{N}_{2} \mathrm{O}$ in a mixed microbial population system: Constraints on $\mathrm{N}_{2} \mathrm{O}$ producing pathways in wastewater treatment. Environ. Sci. Technol. 2013, 47, 1339-1348.

18. Zhang, T.T.; Zhang, J.; Yang, F.; Xie, H.J.; Hu, Z.; Li, Y.R. Effect of temperature on pollutant removal and nitrous oxide emissions of wastewater nitrogen removal system. US Natl. Cent. Biotechnol. Inf. 2012, 33, 1283-1287.

19. Law, Y.; Lant, P.; Yuan, Z. The effect of $\mathrm{pH}$ on $\mathrm{N}_{2} \mathrm{O}$ production under aerobic conditions in a partial nitritation system. Water Res. 2011, 45, 5934-5944.

20. Zhu, X.; Chen, Y.; Chen, H.; Li, X.; Peng, Y.; Wang, S. Minimizing nitrous oxide in biological nutrient removal from municipal wastewater by controlling copper ion concentrations. Appl. Microbiol. Biotechnol. 2013, 97, 1325-1334.

21. Daelman, M.R.J.; van Voorthuizen, E.M.; van Dongen, L.G.J.M.; Volcke, E.I.P.; van Loosdrecht, M.C. Methane and nitrous oxide emissions from municipal wastewater treatment-Results from a long-term study. Water Sci. Technol. 2013, 67, 2350-2355.

22. Shaw, A.R.; Ko, S.-H. Gaseous emissions from wastewater facilities. Water Environ. Res. 2012, 84, 1325-1331.

23. Hiatt, W.C.; Grady, C.P.L., Jr. Application of the activated sludge model for nitrogen to elevated nitrogen conditions. Water Environ. Res. 2008, 80, 2134-2144. 
24. Nopens, I.; Benedetti, L.; Jeppsson, U.; Pons, M.-N.; Alex, J.; Copp, J.B.; Gernaey, K.V.; Rosen, C.; Steyer, J.-P.; Vanrolleghem, P.A. Benchmark simulation model No 2: Finalisation of plant layout and default control strategy. Water Sci. Technol. 2010, 62, 1967-1974.

25. Vanrolleghem, P.A.; Gillot, S. Robustness and economic measures as control benchmark performance criteria. Water Sci. Technol. 2002, 45, 117-126.

26. Haemelinck, S. Evaluatie van sturingsalgoritmen voor de verwijdering van stikstof uit afvalwater (Evaluation of Control Algorithms for Nitrogen Removal from Wastewaters). Engineers Thesis, Ghent University, Gent, Belgium, 2000.

27. Yuan, L.M.; Zhang, C.Y.; Yan, R.; Zhao, G.Z.; Tian, L.J.; He, Z.X.; Liu, H.; Zhang, Y.Q. Advanced wastewater treatment under different dissolved oxygen conditions in an innovative step-feed process. Adv. Mater. Res. 2012, 383-390, 3707-3712.

28. Coen, F.; Vanderhaegen, B.; Boonen, I.; Vanrolleghem, P.A.; van Eyck, L.; van Meenen, P. Nitrogen removal upgrade of a wastewater treatment plant within existing reactor volumes: A simulation supported scenario analysis. Water Sci. Technol. 1996, 34, 339-346.

29. Kessler, R. Stormwater strategies cities prepare aging infrastructure for climate change. Environ. Health Perspect. 2011, 119, 516-519.

30. Sobańtka, A.P.; Zessner, M.; Rechberger, H. Extension of statistical entropy analysis to chemical compounds. Entropy 2012, 14, 2413-2426.

31. Sobańtka, A.P.; Thaler, S.; Zessner, M.; Rechberger, H. Extended statistical entropy analysis for the evaluation of nitrogen budgets in Austria. Int. J. Environ. Sci. Technol. 2013, doi:10.1007/s13762-013-0401-2.

32. Sobańtka, A.P.; Rechberger, H. Extended statistical entropy analysis (eSEA) for improving evaluation of wastewater treatment plants (WWTPs). Water Sci. Technol. 2013, 67, 1051-1057.

33. Ahn, J.H.; Kim, S.; Park, H.; Rahm, B.; Pagilla, K.; Chandran, K. $\mathrm{N}_{2} \mathrm{O}$ emissions from activated sludge processes, 2009-2009: Results of a national monitoring survey in the United States. Environ. Sci. Technol. 2010, 44, 4505-4511.

34. Vanrolleghem, P.A.; Jeppsson, U.; Cartensen, J.; Carlsson, B.; Olsson, G. Integration of wastewater treatment plant design and operation-A systematic approach using cost functions. Water Sci. Technol. 1996, 34, 159-171.

35. Tyagi, V.K.; Chopra, A.K.; Durgapal, N.C.; Kuar, A. Evaluation of daphnia magna as an indicator of toxicity and treatment efficacy of municipal sewage treatment plant. J. Appl. Sci. Environ. Manag. 2007, 11, 61-67.

36. Heijungs, R.; Guinée, J.B.; Huppes, G.; Lankreijer, R.M.; Udo de Haes, H.A.; Sleeswijk, A.W. 1992 Environmental Life Cycle Assessment of Products-Backgrounds; Centre of Environmental Science: Leiden, The Netherlands, 1992.

37. Goedkoop, M.; Spriensma, R. The Eco-Indicator 99 A Damage Oriented Method for Life Cycle Impact Assessment; PRé Consultants B.V.: Amersfoort, The Netherlands, 2000.

38. Guinée, J.B.; Gorée, M.; Heijungs, R.; Huppes, G.; Kleijn, R.; de Koning, A.; van Wegener Oers, L.; Sleeswijk, A.; Suh, S.; Udo de Haes, H.A.; et al. 2002 Handbook on Life Cycle Assessment. Operational Guide to the ISO Standards. I: LCA in Perspective. IIa: Guide. IIb: Operational Annex. III: Scientific Background; Kluwer Academic Publishers: Dordrecht, The Netherlands, 2002; p. 692. ISBM:1-4020-0228-9, 
39. Pennington, D.W.; Margni, M.; Amman, C.; Jolliet, O. Spatial versus non-spatial multimedia fate and exposure modeling: Insights for Western Europe. Environ. Sci. Technol. 2005, 39, $1119-1128$.

40. Pennington, D.W.; Margni, M.; Payet, J.; Jolliet, O. Risk and regulatory hazard based toxicological effect indicators in Life Cycle Assessment (LCA). Hum. Ecotoxicol. Risk Assess. J. 2006, 12, 450-475.

41. Rechberger, H.; Brunner, P.H. A new, entropy based method to support waste and resource management decisions. Environ. Sci. Technol. 2002, 34, 809-816.

42. Shannon, C.E. A mathematical theory of communication. Bell Syst. Technol. J. 1948, 27, 623-656.

43. Tai, S.; Goda, T. Entropy analysis of water and wastewater treatment processes. Int. J. Environ. Stud. 1985, 25, 13-21.

44. Larsen, T.; Gujer, W. The concept of sustainable urban water management. Water Sci. Technol. 1997, 35, 3-10.

45. Kampschreur, M.J.; van der Star, W.R.L.; Wielders, H.A.; Mulder, J.W.; Jetten, M.S.M.; van Loosdrecht, M.C.M. Dynamics of nitric oxide and nitrous oxide emissions during full-scale reject water treatment. Water Res. 2008, 42, 812-826.

46. Verordnung des Bundesministers für Land-und Forstwirtschaft, Umwelt und Wasserwirtschaft über die Festlegung des ökologischen Zustandes für Oberflächengewässer Teil II (Austrian Quality Objective Ordinance-Ecological Status of Surface Waters). Austrian Ministry of Agriculture, Forestry, Environment and Water: Vienna, Austria, 2010.

47. Berenzen, N.; Schulz, R.; Liess, M. Effects of chronic ammonium and nitrite contamination on the macroinvertebrate community in running water microcosms. Water Res. 2001, 35, 3478-3482.

48. Camargo, J.A.; Alonso, A.; Salamanca, A. Nitrate toxicity to aquatic animals: A review with new data for freshwater invertebrates. Chemosphere 2005, 58, 1255-1267.

49. Carpenter, S.R.; Lathrop, R.C. Probabilistic estimate of a threshold for eutrophication. Ecosystems 2008, 11, 601-613.

50. Hamlin, H.J. Nitrate toxicity in Siberian sturgeon (Acipenser baeri). Aquaculture 2006, 253, 688-693.

51. Hannas, B.R.; Das, P.C.; Li, H.; LeBlanc, G.A. Intracellular conversion of environmental nitrate and nitrite to nitric oxide with resulting developmental toxicity to the crustacean daphnia magna. PLoS One 2010, 5, doi:10.1371/journal.pone.0012453.

52. Hickey, C.W.; Martin, M.L. A Review of Nitrate Toxicity to Freshwater Aquatic Species; Report No. R09/57; Environment Canterbury: Canterbury, UK, 2009.

53. De Koekkoek, E. Die ökotoxikologische Ableitung von PNES-Werten für Ammoniak und Nitrit für österreichische Oberflächengewässer (Ecotoxicological Derivation of PNEC-Values for Ammonia and Nitrite for Austrian Surface Waters); Bundessparte Industrie der WKO: Wien, Austria, 2005

(C) 2014 by the authors; licensee MDPI, Basel, Switzerland. This article is an open access article distributed under the terms and conditions of the Creative Commons Attribution license (http://creativecommons.org/licenses/by/3.0/). 